\title{
Case Study: Body Composition Changes Resulting from a Nutritional Intervention on a Professional Vegan Powerlifter
}

\author{
Carlos Hernández-Martínez ${ }^{1}$, Lars Fernández-Rodríguez ${ }^{1}$, Marcos Antonio Soriano ${ }^{2}$ and \\ José Miguel Martínez-Sanz ${ }^{3, *(D)}$ \\ 1 Faculty of Health Sciences, University of Alicante, 03690 Alicante, Spain; \\ carlos-mj23@hotmail.com (C.H.-M.); larsfernandezrodriguez@gmail.com (L.F.-R.) \\ 2 Exercise Physiology Laboratory, Camilo José Cela University, 28692 Madrid, Spain; \\ masoriano1991@gmail.com \\ 3 Department of Nursing, Faculty of Health Sciences, University of Alicante, 03690 Alicante, Spain \\ * Correspondence: josemiguel.ms@ua.es; Tel.: +34-965909806
}

Received: 12 November 2020; Accepted: 2 December 2020; Published: 4 December 2020

\begin{abstract}
Powerlifting is a weight-class strength sport where achieving low fat mass (FM) and high fat-free mass (FFM) is desirable to improve performance. Recent studies have evaluated the nutritional considerations of different eating patterns, such as vegan diets (VD), in athlete populations. VD are a challenge for athletes who want to attain body composition changes. The aim of this case study is to report on the body composition changes and subjective feelings of a male professional vegan powerlifter following VD for six weeks. The body mass of the powerlifter decreased from 79.3 to $77.4 \mathrm{~kg}(2.39 \%)$. Along with this, FM decreased from 15.0 to $11.4 \mathrm{~kg}$ (24\%). Conversely, FFM increased from 64.3 to $66.0 \mathrm{~kg}(2.64 \%)$. Moreover, the powerlifter communicated no subjective feelings of low energy availability during training sessions. The VD might compromise adherence in a nutritional intervention which aims to improve body composition due to the nutritional requirements for fat loss. Therefore, more appropriate health assessments, including blood and psychological tests, are required for professional athletes. This short-term VD intervention was satisfactory for improving body composition and no adverse outcomes were reported.
\end{abstract}

Keywords: vegan; powerlifting; body composition; anthropometry

\section{Introduction}

Powerlifting is a weight-class strength sport that requires the competitor to lift as much weight as possible in three competition lifts (squat, bench press, and deadlift) [1]. The competitors have three attempts for each lift. The best attempt in terms of the amount of weight lifted according to the technical rules is recorded for each lift. Eventually, a total weight lifted is calculated for each lifter based on his/her best attempt in each lift. A system of points is utilized in powerlifting (GL-Points)to evaluate performance. The GL-Points are defined as score that accounts for body mass (BM), total weight lifted and an associated coefficient to calculate its relative strength. Considering this, body composition is a crucial component of powerlifting performance [1].

In order to achieve high performance in powerlifting, it has been suggested that the body composition of a given lifter should be monitored throughout a competition season. In particular, fat-free mass (FFM) [2] and skeletal muscle mass (SMM) are the most determinant variables [3]. Researchers have previously reported that FFM is correlated with powerlifting performance $(\mathrm{r}=0.86$ to $0.95, p \leq 0.001$ ) [2]; however, the latter has also been strongly correlated (mean $r=0.75 \pm 0.17$ ) to longer professional powerlifting careers and body muscle mass variables [3]. While some authors 
have reported that long-term changes in skeletal muscle tissue (hypertrophy) contribute to an increase in strength capacity [4], the contrary has also been reported [5]. Nonetheless, the reason why body composition improvements are a crucial component for powerlifting athletes is still up for debate.

It has been shown that in order to elicit notable changes in body composition, a proper nutrition plan is required [6]. Therefore, to optimize the body composition of a powerlifter, an emerging approach is to apply nutritional periodization strategies [7]. Furthermore, a strength athlete should ensure: sufficient caloric intake to support energetic demands, adequate carbohydrate consumption to fuel the lifter during training, and optimal protein ingestion to support the recovery process [7]. Veganism is a dietary pattern that is adopted and publicized by some high-level athletes. In addition, vegan diets have been shown to confer some health benefits such as reduced risk of heart disease, lower low-density lipoprotein (LDL), blood pressure, type II diabetes, and cancer as compared to its omnivorous counterparts [8]. However, vegan diets tend to be lower in calories, protein, fat, vitamin B12, n-3 fats, calcium, and iodine [9] and, in turn, they tend to be higher in carbohydrates, fiber, micronutrients, phytochemicals, and antioxidants [9]. There are some reports of vegan endurance athletes [10], but this kind of diet remains unexplored in strength athletes.

For this reason, this case study aimed to report body composition changes of a professional vegan powerlifter as well as to report advantages and disadvantages related to the nutritional strategies for six weeks.

\section{Materials and Methods}

\subsection{Patient Information}

The athlete selected for this case study was a young male who followed a vegan eating pattern. The athlete has been involved in the sport of powerlifting for 11 years and became a professional several years ago. In the last decade, he has competed twice in the World Classic Powerlifting Championships, where he ranked 8th in 2012 and 13th in 2019. Moreover, he attended the European Classic Championships on two separate occasions and ranked 8th and 18th in 2017 and 2019, respectively. In addition, he won the National Championship on eight occasions (2010-2012, 2014, 2016-2019) in the $>74 \mathrm{~kg}$ weight class, an overall National Champion in 2013, and a European Classic Cup Champion in 2016.

Vegan eating patterns may be considered a challenge for athletes involved in strength sports who want to attain body composition changes due to various inherent factors of this type of diet: firstly, the high daily protein requirements in strength sports athletes to avoid muscle mass losses and to promote an adequate recovery after training [2]; secondly, the high satiety induced by notable amounts of fiber consumed which may limit food intake, because satiety is one of the main factors that regulates energy intake [11]; and finally, the difficulties when attempting to reach the leucine threshold to maximize muscle synthesis protein [3]. Thus, it was decided to report this case study where a professional powerlifter with a vegan eating pattern voluntarily participated in a nutritional intervention of six weeks within his regular training season.

The powerlifter provided his written informed consent for publication of the data reported here. This study was performed following the declaration of Helsinki and the experimental protocol was approved by the Ethics Committee of the University of Alicante (UA-2020-05-01).

\subsection{Diagnostic Assessment}

Body composition was assessed using two methods: a bioelectrical impedance analysis (BIA) device (model: Tanita BC-418) at week 1 and 6, and anthropometric measurements (ISAK restricted profile) such as the height (weekly), skinfolds, and girths (hip and waist) at week 1, 4, and 6 of the intervention at a standardized time between 9:00-10:00 a.m. (fasted), measured by a certified level 1 ISAK anthropometrist on the right hand side of the body in duplicate or triplicate if the total error of measurement between the first and second measurements was $>5 \%$, after which a mean value was 
obtained [4]. Equations from the kinanthropometry consensus (GREC) and some values provided by the Tanita BC-418 were used to estimate body composition according to the 2-compartment and 4-compartment models [5].

Total daily energy expenditure (TDEE), which is the theoretical maintenance, was estimated using the following equation.

TDEE $(\mathrm{kcal} /$ day $)=($ Basal Metabolic Rate $*$ Non-exercise Activity Thermogenesis $)$

+ Thermic Effect of Food + Exercise Activity Thermogenesis

Non-exercise activity thermogenesis was accounted for as a value between 1 and 2 depending on leisure time activity, and exercise activity thermogenesis was accounted for as a value between 200 and 300 calories per training session.

We also monitored weekly subjective feelings such as satiety, adherence to the nutritional plan, training perception, and other symptoms through some standardized questions via email. All testing was performed by the first author throughout the study.

\subsection{Therapeutic Intervention}

The nutrition intervention started in mid-January 2020 and was rigorously followed by the athlete for 6 weeks (week 1 was the baseline). The nutrition intervention was composed of two phases performed in sequential order. The first phase comprised the first four weeks and following the baseline assessment, a moderate energy restriction (16.5\% of theoretical maintenance calories) was conducted to decrease fat mass for 4 weeks ( $2188 \pm 40 \mathrm{kcal}$ or $34 \mathrm{kcal} / \mathrm{kg} \mathrm{FFM} \mathrm{day}^{-1} ; 3 \mathrm{~g} \mathrm{CHO}$ (carbohydrates) $\mathrm{kg} \mathrm{day}^{-1}$, $2.2 \mathrm{~g}$ PRO (protein) $\mathrm{kg} \mathrm{day}^{-1}$ or $2.7 \mathrm{~g}$ PRO kg FFM day ${ }^{-1}$, and $0.8 \mathrm{~g}$ FAT (fats) $\mathrm{kg} \mathrm{day}^{-1}$ ) $[6,7,9,12]$. The latter phase was performed during the following weeks. The athlete adhered to a diet break protocol, where calories were raised to maintenance $\left(2730 \pm 50 \mathrm{kcal}\right.$ or $42 \mathrm{kcal} \mathrm{kg} \mathrm{FFM} \mathrm{day}^{-1}, 4.7 \mathrm{~g} \mathrm{CHO} \mathrm{kg} \mathrm{day}^{-1}$, $1.8 \mathrm{~g} \mathrm{PRO} \mathrm{kg} \mathrm{day}^{-1}$ and $0.95 \mathrm{~g}$ FAT kg day ${ }^{-1}$ ) [12]. Furthermore, the athlete was instructed to consume a series of supplements such as soy protein powder ( $76 \%$ of protein), monohydrate creatine, vitamin B12, vitamin D, and n-3 fatty acids (seaweed-based) due to potential deficiencies derived from the diet and lifestyle [13].

Shown in Table 1 are examples of the menu, including supplements, during the intervention. The tastes and preferences of the athlete were considered in the design of the menu to promote greater adherence. The athlete estimated his compliance with the prescribed diet at approximately 90 to $95 \%$. 
Table 1. Example of vegan diet planning for phase 1 and 2.

\begin{tabular}{|c|c|c|c|c|}
\hline & \multicolumn{2}{|c|}{ Phase 1} & \multicolumn{2}{|c|}{ Phase 2} \\
\hline & Day 1 & Day 2 & Day 3 & Day 4 \\
\hline Breakfast & $\begin{array}{c}100 \mathrm{~g} \text { chickpea hummus }+1 \text { carrot }+5 \mathrm{~g} \\
\text { olive oil }+100 \mathrm{~g} \text { oat milk }+50 \mathrm{~g} \text { soy } \\
\text { protein powder }+125 \mathrm{~g} \text { soy yoghurt } \\
2 \text { omega- } 3 \text { pearls }\end{array}$ & $\begin{array}{c}250 \mathrm{~g} \text { oat milk }+20 \mathrm{~g} \text { of cornflakes }+15 \mathrm{~g} \\
\text { peanut butter }+40 \mathrm{~g} \text { soy protein powder }+ \\
100 \mathrm{~g} \text { fruit } \\
1 \text { omega- } 3 \text { pearl }\end{array}$ & $\begin{array}{c}200 \mathrm{~g} \text { oat milk }+35 \mathrm{~g} \text { soy protein powder }+ \\
100 \mathrm{~g} \text { fruit } \\
200 \mathrm{~g} \text { chickpea hummus }+1 \text { carrot }+5 \mathrm{~g} \\
\text { olive oil }\end{array}$ & $\begin{array}{c}25 \mathrm{~g} \text { oat flour }+200 \mathrm{~g} \text { rice milk }+40 \mathrm{~g} \\
\text { soy protein powder } \\
65 \mathrm{~g} \text { bread }+5 \mathrm{~g} \text { olive oil }+20 \mathrm{~g} \text { nuts }+ \\
2 \text { omega- } 3 \text { pearls }\end{array}$ \\
\hline Snack & $\begin{array}{l}65 \mathrm{~g} \text { bread }+5 \mathrm{~g} \text { olive oil }+80 \mathrm{~g} \\
\quad \text { canned lentils } \\
30 \mathrm{~g} \text { soy protein powder }+100 \mathrm{~g} \\
\text { fruit (shake) }\end{array}$ & $\begin{array}{c}70 \mathrm{~g} \text { frozen rice with vegetable }+70 \mathrm{~g} \\
\text { textured soy }+200 \mathrm{~g} \text { red pepper }+\frac{1}{2} \text { onion } \\
+10 \mathrm{~g} \text { olive oil } \\
100 \mathrm{~g} \text { grapes }+1 \text { omega- } 3 \text { pearl }\end{array}$ & $\begin{array}{c}65 \mathrm{~g} \text { bread }+25 \mathrm{~g} \text { nuts }+5 \mathrm{~g} \text { olive oil }+ \\
100 \mathrm{~g} \text { canned lentils (homemade burger) } \\
100 \mathrm{~g} \text { fruit }+2 \text { omega- } 3 \text { pearls }\end{array}$ & $\begin{array}{c}400 \mathrm{~g} \text { frozen rice with vegetables }+ \\
100 \mathrm{~g} \text { canned beans }+100 \mathrm{~g} \text { of tofu }+ \\
10 \mathrm{~g} \text { olive oil } \\
100 \mathrm{~g} \text { soy yoghurt }+100 \mathrm{~g} \text { banana }\end{array}$ \\
\hline Lunch & $\begin{array}{l}250 \mathrm{~g} \text { canned legumes }+50 \mathrm{~g} \text { textured } \\
\text { soy }+100 \mathrm{~g} \text { vegetables }+10 \mathrm{~g} \text { olive oil }\end{array}$ & $\begin{array}{c}200 \mathrm{~g} \text { sweet potatoes }+100 \mathrm{~g} \text { pumpkin }+ \\
200 \mathrm{~g} \text { seitan }+100 \mathrm{~g} \text { canned lentils }+10 \mathrm{~g} \\
\text { olive oil } \\
100 \mathrm{~g} \text { fruit }\end{array}$ & $\begin{array}{c}80 \mathrm{~g} \text { rice }+200 \mathrm{~g} \text { canned beans }+120 \mathrm{~g} \\
\text { fajitas }+100 \mathrm{~g} \text { seitan }+10 \mathrm{~g} \text { olive oil }+100 \mathrm{~g} \\
\text { vegetables }\end{array}$ & $\begin{array}{c}120 \mathrm{~g} \text { pasta }+50 \mathrm{~g} \text { textured soy }+50 \mathrm{~g} \\
\text { fried tomato }+10 \mathrm{~g} \text { olive oil }+200 \mathrm{~g} \\
\text { vegetables } \\
100 \mathrm{~g} \text { fruit }\end{array}$ \\
\hline Dinner & $\begin{array}{c}30 \mathrm{~g} \text { rice }+200 \mathrm{~g} \text { canned beans }+40 \mathrm{~g} \\
\text { fajitas }+150 \mathrm{~g} \text { seitan }+10 \mathrm{~g} \text { olive oil }+ \\
100 \mathrm{~g} \text { vegetables } \\
100 \mathrm{~g} \text { fruit }\end{array}$ & $\begin{array}{l}100 \mathrm{~g} \text { soy yoghurt }+1 \mathrm{ud} \text { Weetabix }+15 \mathrm{~g} \\
\text { Brazilian nuts }+250 \mathrm{~g} \text { fruit }+40 \mathrm{~g} \text { soy } \\
\text { protein powder }+10 \mathrm{~g} \text { dates }\end{array}$ & $\begin{array}{c}200 \mathrm{~g} \text { baked legumes }+30 \mathrm{~g} \text { textured soy }+ \\
100 \mathrm{~g} \text { vegetables }+10 \mathrm{~g} \text { olive oil } \\
100 \mathrm{~g} \text { of banana }\end{array}$ & $\begin{array}{c}65 \mathrm{~g} \text { whole grain bread }+5 \mathrm{~g} \text { olive oil }+ \\
50 \mathrm{~g} \text { seitan }+50 \mathrm{~g} \text { tomato } \\
200 \mathrm{~g} \text { fruit }\end{array}$ \\
\hline Kcal and macronutrients & $\begin{array}{l}\text { Energy: } 2192 \text { kcal—CHO: } 244 \text { g—PRO: } \\
\quad 172 \text { g—FAT: } 58 \mathrm{~g}\end{array}$ & $\begin{array}{l}\text { Energy: } 2169 \text { kcal—CHO: } 245 \mathrm{~g} \text { —PRO: } \\
170 \text { g—FAT: } 58 \mathrm{~g}\end{array}$ & $\begin{array}{l}\text { Energy: } 2720 \text { kcal—CHO: } 362 \text { g—PRO: } \\
140 \text { g_FAT: } 71 \mathrm{~g}\end{array}$ & $\begin{array}{c}\text { Energy: } 2723 \mathrm{kcal} — \text { CHO: } 365 \mathrm{~g} \text { —PRO: } \\
142 \text { g—FAT: } 74 \mathrm{~g}\end{array}$ \\
\hline Supplements & \multicolumn{2}{|c|}{ Dose and Frequency } & \multicolumn{2}{|c|}{ Comments and Remarks } \\
\hline Creatine monohydrate & \multicolumn{2}{|c|}{$3-5 \mathrm{~g} \mathrm{day}^{-1}$ (maintenance doses) } & \multicolumn{2}{|c|}{$\begin{array}{l}\text { Data indicates that creatine supplementation might be most beneficial for athletes with } \\
\text { low pre-existing muscle creatine stores [13] }\end{array}$} \\
\hline Vitamin B12 & \multicolumn{2}{|c|}{$2000 \mu \mathrm{g}$ (weekly) [13] } & \multicolumn{2}{|c|}{ Absence of animal and dairy products increases the risk of deficiency. } \\
\hline Omega 3 & \multicolumn{2}{|c|}{ 1-2 g microalgae oil day ${ }^{-1}$ (combined EPA and DHA) [13] } & \multicolumn{2}{|l|}{-} \\
\hline Vitamin D3 & \multicolumn{2}{|c|}{2000 UI day $^{-1}$} & \multicolumn{2}{|l|}{ - } \\
\hline \multirow{3}{*}{ Soy protein powder } & \multicolumn{2}{|c|}{ Mean intake during phase $1: 80 \mathrm{~g}$ ( $60.8 \mathrm{~g}$ of protein) } & \multicolumn{2}{|c|}{ Grams and percentage of protein from protein powder } \\
\hline & \multicolumn{2}{|c|}{ Mean intake during phase 2: $37.5 \mathrm{~g}$ ( $28.5 \mathrm{~g}$ of protein $)$} & \multicolumn{2}{|c|}{ Phase 1: $60.8 \mathrm{~g}$ of $170 \mathrm{~g}(35.8 \%$ of total protein intake $)$} \\
\hline & \multicolumn{2}{|c|}{ Day 1: 80 g; Day 2: 80 g; Day 3: 35 g; Day 4: $40 \mathrm{~g}$} & \multicolumn{2}{|c|}{ Phase 2: $28.5 \mathrm{~g}$ of $140 \mathrm{~g}(20.3 \%$ of total protein intake $)$} \\
\hline
\end{tabular}




\section{Results}

\section{Follow-Up and Outcomes}

The anthropometric and descriptive characteristics at baseline of the intervention are shown in Table 2.

Table 2. Anthropometric characteristics at baseline.

\begin{tabular}{lc}
\hline Characteristic & Value \\
\hline Age (y) & 28 \\
Height (cm) & 166.5 \\
Body mass (kg) (Tanita BC418) & 79.3 \\
Fat-free mass (kg) (Tanita BC418) & 64.3 \\
Fat mass (kg) (Tanita BC418) & 15 \\
\% of fat mass (Carter equation) & 8.6 \\
Bone mass (kg) (Rocha equation) & 9.5 \\
Skeletal muscle mass (kg) (Lee equation) & 36.1 \\
Weight class (kg) & -83 \\
Sum of 8 skinfolds (mm) * & 74.8 \\
Fat mass (\%) (calculated from Tanita BC418) & 18.9 \\
Hip circumference (cm) & 89 \\
Waist circumference (cm) & 99.2 \\
Hip-to-waist ratio & 0.9 \\
Basal metabolic rate (BMR) (kcal) & 1891 \\
\hline Triceps + Subscapular + Biceps + Iliac crest + supraspinal + Abdomen + Thigh + Calf.
\end{tabular}

At the completion of the first phase, the BM of the powerlifter decreased from 79.3 to $77.4 \mathrm{~kg}$ $(2.39 \%)$ (see Figure 1$)$. The mean weekly weight loss was about $0.470 \mathrm{~g}(0.59 \%$ of BM). In addition, fat mass (FM) decreased from 15.0 to $11.4 \mathrm{~kg}(24 \%)$. Conversely, FFM increased from 64.3 to $66.0 \mathrm{~kg}$ (2.64\%). Hip and waist circumferences were reduced by $5.62 \%(89.0$ to $84.0 \mathrm{~cm})$ and $2.22 \%(99.2$ to $97.0 \mathrm{~cm}$ ), respectively. The hip-to-waist ratio decreased by $3.37 \%$ (from 0.89 to $0.86 \mathrm{~cm}$ ). These data are shown in Table 3.

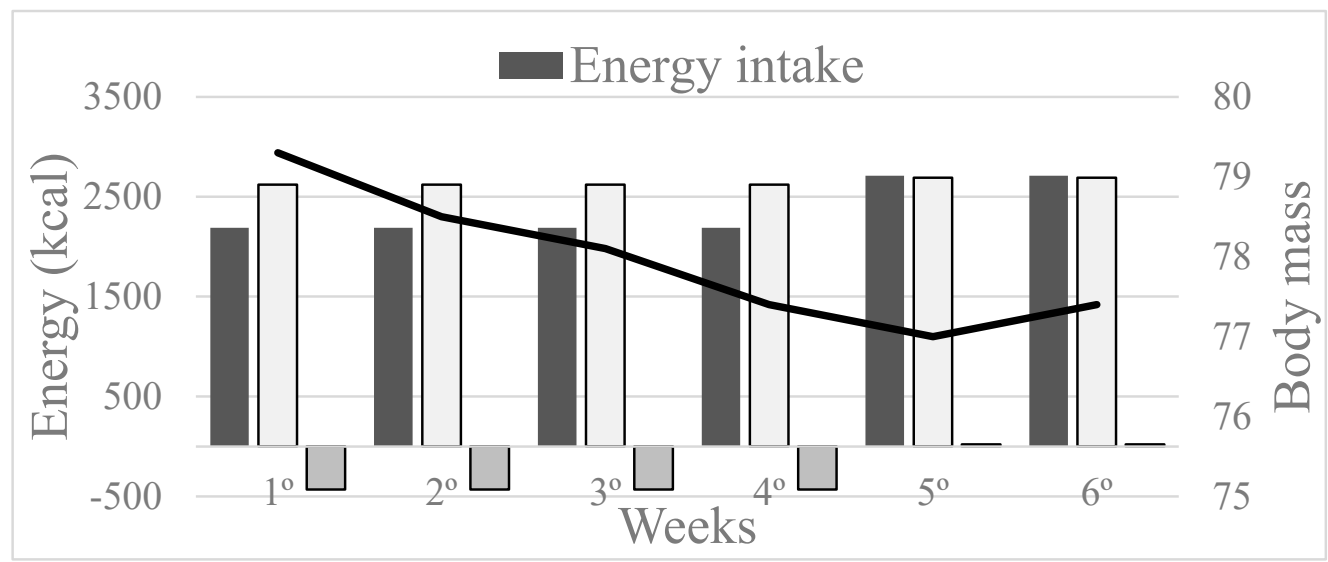

Figure 1. Energy intake, energy expenditure, energy balance, and their relationship with body mass for 6 weeks. 
Table 3. Body mass, fat-free mass, fat mass, hip circumference, waist circumference, abdominal sagittal diameter (mm) and hip-to-waist ratio changes for 6 weeks.

\begin{tabular}{ccccccccc}
\hline Weeks & $\begin{array}{c}\text { Body Mass } \\
(\mathbf{k g})\end{array}$ & $\begin{array}{c}\text { Fat-Free } \\
\text { Mass (kg) }\end{array}$ & $\begin{array}{c}\text { Fat Mass } \\
(\mathbf{k g})\end{array}$ & $\begin{array}{c}\text { Fat Mass } \\
\mathbf{( \% )}\end{array}$ & $\begin{array}{c}\text { Hip } \\
\text { Circumference } \\
(\mathbf{m m})\end{array}$ & $\begin{array}{c}\text { Waist } \\
\text { Circumference } \\
(\mathbf{m m})\end{array}$ & $\begin{array}{c}\text { Abdominal } \\
\text { Sagittal } \\
\text { Diameter (mm) }\end{array}$ & $\begin{array}{c}\text { Hip-to-Waist } \\
\text { Ratio }\end{array}$ \\
\hline 1 & 79.3 & 64.3 & 15.0 & 18.9 & 89.0 & 99.2 & 20.5 & 0.89 \\
2 & 75.8 & - & - & - & - & - & - & - \\
3 & 78.1 & - & - & - & - & - & - & - \\
4 & 77.4 & - & - & - & - & - & - & - \\
5 & 77.0 & - & - & - & - & - & - & 0.86 \\
6 & 77.4 & 66.0 & 11.4 & 14.7 & 84.0 & 97.0 & 19.9 & \\
\hline
\end{tabular}

The powerlifter communicated to have been training in regular conditions throughout the nutritional intervention. Moreover, a subjective feeling of satiety and absence of low-energy availability were consistently reported during the intervention. These positive reports allowed him to avoid modifications to his regular training.

\section{Discussion}

This study may be the first case report on changes in body composition following a short-term vegan diet of a professional vegan powerlifter.

The results suggest that the phenomenon known as "body recomposition" could have occurred in an advanced athlete as it was previously reported by Barakat and colleagues [14]. A plausible explanation to this phenomenon could have been the improvement in meal planning compared to what the athlete ate before the intervention. On the other hand, a potential limitation to explain this would be the use of the measurement techniques.

Further advantages provided by this nutritional plan were the following: high satiety despite a low energy intake and the combination of whole foods and supplements to improve the profile of the specific intake of amino acids [3]. On the contrary, several disadvantages may be also highlighted. These were the high amounts of soy protein supplement, which may reduce the variability of the nutritional plan and compromise adherence, and an insufficient intake of some micronutrients such as calcium, iron, zinc, and magnesium due to a low energy budget [15].

There is a certain relationship between the weight lost and performance via the improvement of the power-to-weight ratio, which is particularly desired in weight-class sports such as powerlifting. A decrease in BM could lead to lean body mass (LBM) or FFM loss. However, it has also been suggested that $\mathrm{BM}$ reductions throughout the season should be achieved in a slow fashion when the main goal is to preserve skeletal muscle mass [9]. It has been suggested that losing $0.7 \%$ of $\mathrm{BM}$ per week might be better than 1-1.4\% of BM for athletes who would like to preserve or gain LBM and strength [16]. Nonetheless, it was also recently reported that a gradual weight loss is associated with greater loss in FM and body fat percentage, but it was not associated with changes in FFM in overweight and obese adults and older individuals [17]. Our results show that the athlete's mean weekly weight loss during the first four weeks of the intervention $(0.47 \mathrm{~kg} /$ week) was consistent with results reported by some authors [9], while others recommended minor weekly weight losses in physique athletes $(<0.5 \%$ of BM per week) [18]. It should be mentioned that these nutritional recommendations were obtained for bodybuilders, whose body fat percentage tends to be lower during the season. Moreover, the magnitude of the energy deficit [19], the rate of BM loss per week [20], nutritional considerations such as timing, protein intake, etc., and the body composition assessment methods employed could help explain FFM variations along the weight loss phase.

Athletes involved in weight-class sports are advised to optimize protein intake since the preservation of FFM and relative strength is likely advantageous to performance [13]. There is a relationship between dietary protein intake, energy balance status, and the preservation of LBM. It should be acknowledged that the stimulation of muscle protein synthesis (MPS) is thought to be one of the most relevant physiological variables responsible for the maintenance of, or gains in, skeletal 
muscle mass in any energy balance condition [21]. The most determinant variables for augmenting MPS are dietary protein and exercise, in particular resistance exercises [22]. However, negative energy balance downregulates MPS [23]. High-protein diets play the main dietary role in reducing FFM losses during energy restriction (ER) [2,23], mitigating MPS decreases [23] and achieving a positive net protein balance which determines the area under the MPS/muscle protein breakdown (MPB)) relationship [21]. The recommended protein range for athletes undergoing ER with resistance exercises is 2.3-3.1 $\mathrm{g}$ PRO kg FFM day ${ }^{-1}$ [9]. However, vegan athletes might consider the upper limit of the recommended protein intake $\left(2.2 \mathrm{~g} \mathrm{~kg} \mathrm{day}^{-1}\right.$ in a period of energy surplus or $3.1 \mathrm{~g} \mathrm{~kg} \mathrm{FFM} \mathrm{day}^{-1}$ in a period of ER) [12,24] as a method to prevent possible essential amino acid deficiencies. We should also consider the difference between "effective" and "optimal" ranges and their relationship with sustainability when setting macronutrient goals.

One of the most important strategies employed to meet protein requirements for athletes is the consumption of plant-based protein supplementation, particularly if achieving sufficient protein via whole foods is either difficult or inconvenient [13]. However, protein supplementation is required for athletes in order to reach high amounts of protein requested for this sport, which are far above the normal requests [25]. There is an ongoing debate about the anabolic properties of protein food sources. It has been demonstrated that protein quantity and quality play a determinant role in increasing MPS [26]. The latter was defined as the proportion of amino acids, especially considering the leucine concentrations, which seems to be determinant for maximizing MPS [27]. The athlete consumed soy protein powder due to soy being one of the only plant-based proteins that have been studied in detail for MPS responses [3]. Tang et al. [28] reported that soy protein isolates increased MPS at similar rates to whey in rest conditions, while after resistance exercises, whey protein increased MPS at higher rates in young subjects. The differences in leucine content between whey [29] and soy might be the key factor responsible for the greater capacity to stimulate postprandial MPS rates post-exercise due to the exercise sensitizing the muscle to hyperaminoacidemia and increasing its capacity to use amino acids [3]. Thus, to maximize MPS, a higher intake of protein is therefore required post-exercise [22]. However, in rest conditions, soy protein increases MPS at the same rates as whey protein.

The nutritional intervention had several limitations related to the accuracy and reliability of the measurements due to the methods of BM and body composition estimation employed, and the absence of blood tests to monitor and assess relevant health biomarkers. This is particularly important for a professional powerlifter whose eating pattern may predispose him to macronutrient and micronutrient deficiencies [8]. In addition, the athlete's subjective training feelings were monitored weekly through questions via email; however, no objective measurements were taken to test training progression.

\section{Conclusions}

A 6-week vegan dietary intervention improved the body composition of an elite powerlifter during the off-season. Nutritional recommendations for athletes should be followed for those who adhere to a vegan eating pattern to optimize the desired changes in body composition. The advantages and disadvantages of this eating pattern should also be considered. Further cases on elite vegan athletes are requested to better address the strengths and weaknesses of this dietary pattern. Despite this, the testimonials of athletes should be also considered.

Author Contributions: C.H.-M. and J.M.M.-S. designed the study; M.A.S. and J.M.M.-S. reviewed and supervised the study; C.H.-M. data collection; C.H.-M. and L.F.-R. interpreted the data; C.H.-M. and M.A.S., wrote the manuscript; C.H.-M., L.F.-R., M.A.S. and J.M.M.-S. reviewed and edited the manuscript. All authors have read and agreed to the published version of the manuscript.

Funding: This research received no external funding.

Acknowledgments: The authors would like to thank the powerlifter JPC for his collaboration in sharing the information reported here. We are grateful to David Walker and Mario Fon (native English speakers) for their review of the English grammar and style of the current report. We are grateful to dietopro ${ }^{\circledR}$ for the assignment of this nutritional software. 
Conflicts of Interest: The authors declare no conflict of interest.

$\begin{array}{ll}\text { Abbreviations } \\ \text { BIA } & \text { bioelectrical impedance analysis } \\ \text { BM } & \text { body mass }(\mathrm{kg}) \\ \text { CHO } & \text { dietary carbohydrate }(\mathrm{g}) \\ \text { DXA } & \text { dual-energy X-ray absorptiometry } \\ \text { ER } & \text { energy restriction }(\% \text { or kcal) } \\ \text { FAT } & \text { dietary fat }(\mathrm{g}) \\ \text { FFM } & \text { fat-free mass }(\mathrm{kg}) \\ \text { FM } & \text { fat mass }(\mathrm{kg}) \\ \text { LBM } & \text { lean body mass }(\mathrm{kg}) \\ \text { LDL } & \text { low-density lipoprotein } \\ \text { MPB } & \text { muscle protein breakdown } \\ \text { MPS } & \text { muscle protein synthesis } \\ \text { PRO } & \text { dietary protein (g) } \\ \text { SSM } & \text { skeletal muscle mass } \\ \text { TDEE } & \text { total daily energy expenditure (kcal/day) }\end{array}$

\section{References}

1. Nebl, J.; Haufe, S.; Eigendorf, J.; Wasserfurth, P.; Tegtbur, U.; Hahn, A. Exercise capacity of vegan, lacto-ovo-vegetarian and omnivorous recreational runners. J. Int. Soc. Sports Nutr. 2019, 16, 23. [CrossRef] [PubMed]

2. Phillips, S.M.; van Loon, L.J.C. Dietary protein for athletes: From requirements to optimum adaptation. J. Sports Sci. 2011, 29, 29-38. [CrossRef] [PubMed]

3. Van Vliet, S.; Burd, N.A.; van Loon, L.J. The Skeletal Muscle Anabolic Response to Plant-versus Animal-Based Protein Consumption. J. Nutr. 2015, 145, 1981-1991. [CrossRef] [PubMed]

4. Cabañas Armesilla, M.; Esparza Ros, F. Compendio de Cineantropometria; CTO Editorial: Madrid, Spain, 2010.

5. Alvero Cruz, J.R.; Cabañas Armesilla, M.D.; Herrero de Lucas, A.; Martinez Riaza, L.; Moreno Pascual, C.; Porta Manzañino, J.; Sillero Quintana, M.; Sirvent Belando, J.E. Protocolo de valoración de la composición corporal para el reconocimiento médico-deportivo. Doc. Consenso Grupo Español Cineantropometría (Grec) Fed. Española Med. Deporte (Femede) 2010, 16, 166-179.

6. Melin, A.K.; Heikura, I.A.; Tenforde, A.; Mountjoy, M. Energy availability in athletics: Health, performance, and physique. Int. J. Sport Nutr. Exerc. Metab. 2019, 29, 152-164. [CrossRef] [PubMed]

7. Cholewa, J.M.; Newmire, D.E.; Zanchi, N.E. Carbohydrate restriction: Friend or foe of resistance-based exercise performance? Nutrition 2019, 60, 136-146. [CrossRef] [PubMed]

8. Appleby, P.N.; Key, T.J. The long-term health of vegetarians and vegans. Proc. Nutr. Soc. 2016, 75, $287-293$. [CrossRef] [PubMed]

9. Helms, E.R.; Aragon, A.A.; Fitschen, P.J. Evidence-based recommendations for natural bodybuilding contest preparation: Nutrition and supplementation. J. Int. Soc. Sports Nutr. 2014, 11, 1-20. [CrossRef] [PubMed]

10. Leischik, R.; Spelsberg, N. Vegan Triple-Ironman (Raw Vegetables/Fruits). Available online: https://www. hindawi.com/journals/cric/2014/317246/ (accessed on 29 November 2020).

11. Hopkins, M.; Blundell, J.E. Energy balance, body composition, sedentariness and appetite regulation: Pathways to obesity. Clin. Sci. 2016, 130, 1615-1628. [CrossRef]

12. Kerksick, C.M.; Wilborn, C.D.; Roberts, M.D.; Smith-Ryan, A.; Kleiner, S.M.; Jäger, R.; Collins, R.; Cooke, M.; Davis, J.N.; Galvan, E.; et al. ISSN exercise \& sports nutrition review update: Research \& recommendations. J. Int. Soc. Sports Nutr. 2018, 15, 1-57. [CrossRef]

13. Iraki, J.; Fitschen, P.; Espinar, S.; Helms, E.R. Nutrition Recommendations for Bodybuilders in the Off-Season: A Narrative Review. Sports 2019, 7, 154. [CrossRef] [PubMed]

14. Rogerson, D. Vegan diets: Practical advice for athletes and exercisers. J. Int. Soc. Sports Nutr. 2017, 14, 1-15. [CrossRef] [PubMed] 
15. Barakat, C.; Pearson, J.; Escalante, G.; Campbell, B.; De Souza, E.O. Body Recomposition: Can Trained Individuals Build Muscle and Lose Fat at the Same Time? Strength Cond. J. 2020, 42, 7-21. [CrossRef]

16. Thomas, D.T.; Erdman, K.A.; Burke, L.M. Position of the Academy of Nutrition and Dietetics, Dietitians of Canada, and the American College of Sports Medicine: Nutrition and Athletic Performance. J. Acad. Nutr. Diet. 2016, 116, 501-528. [CrossRef] [PubMed]

17. Garthe, I.; Raastad, T.; Refsnes, P.E.; Koivisto, A.; Sundgot-Borgen, J. Effect of two different weight-loss rates on body composition and strength and power-related performance in elite athletes. Int. J. Sport Nutr. Exerc. Metab. 2011, 21, 97-104. [CrossRef] [PubMed]

18. Larky, D.A.; Bagheri, R.; Abbasnezhad, A.; Tinsley, G.M.; Alipour, M.; Wong, A. Effects of gradual weight loss vs rapid weight loss on body composition and resting metabolic rate: A systematic review and meta-analysis. Br. J. Nutr. 2020, 124, 1121-1132. [CrossRef]

19. Roberts, B.M.; Helms, E.R.; Trexler, E.T.; Fitschen, P.J. Nutritional Recommendations for Physique Athletes. J. Hum. Kinet. 2020, 71, 79-108. [CrossRef]

20. Robinson, S.L.; Morton, J.P.; Close, G.L.; Flower, D.; Bannock, L. Nutrition Intervention for an International-Standard Female Football Player Introduction and Background. J. Appl. Case Stud. Sport Exerc. Sci. 2014, 1, 17-28.

21. Rossow, L.M.; Fukuda, D.H.; Fahs, C.A.; Loenneke, J.P.; Stout, J.R. Natural bodybuilding competition preparation and recovery: A 12-month case study. Int. J. Sports Physiol. Perform. 2013, 8, 582-592. [CrossRef]

22. Tipton, K.D.; Wolfe, R.R. Protein and amino acids for athletes. J. Sports Sci. 2004, 22, 65-77. [CrossRef]

23. Stokes, T.; Hector, A.J.; Morton, R.W.; McGlory, C.; Phillips, S.M. Recent perspectives regarding the role of dietary protein for the promotion of muscle hypertrophy with resistance exercise training. Nutrients 2018, 10, 180. [CrossRef] [PubMed]

24. Carbone, J.W.; McClung, J.P.; Pasiakos, S.M. Recent Advances in the Characterization of Skeletal Muscle and Whole-Body Protein Responses to Dietary Protein and Exercise during Negative Energy Balance. Adv. Nutr. 2019, 10, 70-79. [CrossRef] [PubMed]

25. Baroni, L.; Goggi, S.; Battino, M. VegPlate: A Mediterranean-Based Food Guide for Italian Adult, Pregnant, and Lactating Vegetarians. J. Acad. Nutr. Diet. 2018, 118, 2235-2243. [CrossRef]

26. Morton, R.W.; McGlory, C.; Phillips, S.M. Nutritional interventions to augment resistance training-induced skeletal muscle hypertrophy. Front. Physiol. 2015, 6, 245. [CrossRef] [PubMed]

27. Van Loon, L.J.C. Leucine as a pharmaconutrient in health and disease. Curr. Opin. Clin. Nutr. Metab. Care 2012, 15, 71-77. [CrossRef] [PubMed]

28. Tang, J.E.; Moore, D.R.; Kujbida, G.W.; Tarnopolsky, M.A.; Phillips, S.M. Ingestion of whey hydrolysate, casein, or soy protein isolate: Effects on mixed muscle protein synthesis at rest and following resistance exercise in young men. J. Appl. Physiol. 2009, 107, 987-992. [CrossRef] [PubMed]

29. Burd, N.A.; Hamer, H.M.; Pennings, B.; Pellikaan, W.F.; Senden, J.M.G.; Gijsen, A.P.; van Loon, L.J.C. Substantial Differences between Organ and Muscle Specific Tracer Incorporation Rates in a Lactating Dairy Cow. PLoS ONE 2013, 8, e68109. [CrossRef]

Publisher's Note: MDPI stays neutral with regard to jurisdictional claims in published maps and institutional affiliations.

(C) 2020 by the authors. Licensee MDPI, Basel, Switzerland. This article is an open access article distributed under the terms and conditions of the Creative Commons Attribution (CC BY) license (http://creativecommons.org/licenses/by/4.0/). 